\title{
VODENJE V SLOVENSKI VOJSKI
}

Povzetek V članku želimo predstaviti vodenje v Slovenski vojski v širšem in ožjem smislu ter nerešena vprašanja na različnih ravneh. Vodenje je proces in ne le dolžnost in tako bi ga morali tudi razumeti. Vodenje ne poteka le do določene ravni znotraj vojaške organizacije, temveč je pomemben proces pri delu z ljudmi. Rezultate in ugotovitve bomo lahko uporabili za lažje razumevanje vodenja in nedorečenosti tega pojava, na drugi strani pa za lažje razumevanje nujnosti zavedanja pomembnosti sodobnih izzivov vodenja. Prispevek omogoča bralcu celovit vpogled v vodenje v hierarhični organizaciji, kot je Slovenska vojska.

Ključne besede

\section{Vodenje, vojaško vodenje, Slovenska vojska, poveljevanje.}

Abstract The purpose of the article is to present leadership in the Slovenian Armed Forces (SAF) both in a broader and narrower sense as well as to present the unresolved issues at various levels. Leadership is a process not just a duty and should therefore be perceived as such. It is not applied just up to a certain level within a military organization, but is a key process in working with people. The results and findings of this article can be used to facilitate the understanding of leadership and the obvious vagueness of this phenomenon, and on the other hand to enable a better comprehension of how important it is to realize the importance of contemporary leadership challenges. The article provides the reader with a comprehensive insight into leadership in a hierarchical organization such as the SAF.

Key words Leadership, military leadership, Slovenian Armed Forces, command. 
Uvod Pri svojem delu, to je pri poučevanju vodenja in menedžmenta v SV ter iz Strateškega pregleda obrambe 2016, pri čemer je kot enega od razlogov, ki so negativno vplivali na delovanje in razvoj SV vse od leta 2009, zaslediti nestabilnost vojaškega voditeljstva (Sklepi strateškega pregleda obrambe, 2017, str. 29), smo v prispevku kot problematičnega izpostavili in obravnavali predvsem vodenje (v ožjem in širšem smislu) v SV, s poudarkom, da je razumevanje in zavedanje sodobnih izzivov pri vodenju manjkajoči člen $\mathrm{v}$ učinkovitem in uspešnem vodenju posameznikov in organizacije.

Prispevek se nanaša na področje vodenja. Z vodenjem se srečujemo hote ali nehote v različnih situacijah in v vsakdanjem življenju, in sicer v službi, družini, prostovoljnih organizacijah, državi ipd. Brez vodenja bi si težko predstavljali organizirano delovanje človeštva. Strinjamo se s Sharmo, ki pravi, da je vodenje bistvo življenja in da se vse začne od znotraj - temelj je samodisciplina, saj brez nje ni mogoče voditi in poznati samega sebe (Sharma, 2017, str. 47).

Vojaki danes delujejo v drugačnem okolju kot pred dvajsetimi leti. Na novo okolje so vplivale predvsem spremenjene varnostne okoliščine, nove vrste in načini bojevanja, sodobni izzivi vodenja, asimetrične grožnje ipd. Vse to zahteva od vodij, da spremenijo načine razmišljanja in slog vodenja svojih podrejenih, da dopolnijo svoje znanje s širšim kulturološkim zavedanjem, upravljanjem sprememb, etičnim delovanjem ipd.

\section{VODENJE}

Fenomen vodenja in voditeljstva zasledimo že pred našim štetjem in že takrat je bil to predmet proučevanja in raziskovanja. Kot pravi Ahmed, so v preteklosti vladarji svojo moč črpali in uveljavljali, ker jim jo je podelil Bog ali kakšno drugo mitološko bitje. Torej so takratni vodje vodili svoje podrejene le, ker so se rodili v pravo družino ali poveljevali najmočnejšim vojskam. Največkrat je to pomenilo, da so vodje bili avtoritarni, izolirani od svojih podrejenih, zahtevali so neomajno poslušnost, uporabljali so ustrahovanje in zlorabljanje kot prevladujoča načina vodenja (Ahmed, 2016, e-vir).

Danes je vodenje še vedno zelo aktualen predmet proučevanja, zato so znane številne definicije. Maxwell v svoji knjigi Developing the leader within you zelo posrečeno razloži, čemu ta poplava definicij vodenja. Pove, da vsi govorijo o vodenju, redki ga razumejo, večina si ga želi in le redki ga dosežejo (Maxwell, 1993, str. 1). Strinjamo se tudi s trditvijo Brezovška in Kukoviča, da vodenje spada med enega najbolj opazovanih in najmanj razumljenih fenomenov na svetu (Brezovšek in Kukovič, 2014, str. 7).

Kot pravi Fairholm, obstaja danes več zmede in razprav o tem, kaj je vodenje, kot kadar koli prej. Vendar pa je tudi velik napredek pri razumevanju, kaj vodenje je. Vodenje je treba še naprej postavljati v kontekst, ki ga je mogoče zlahka razumeti, 
tako da bo razprava koristnejša, poučnejša in produktivnejša $\mathrm{v}$ prizadevanju za razumevanje prave narave vodenja. Vodenje ljudje sprejemajo, celo hrepenijo po njem, a le redko dovolj razumejo, da bi ga opisali. Vodenje je dejansko filozofija, ki so jo sprejeli le nekateri, je pa implicitno razumljena pri večini. Kot takega se lahko naučijo, ga razumejo in uporabijo ljudje, ki imajo smisel zanj. Etika vodenja ni nujno zasnovana v njenih filozofskih podlagah, temveč v dejanski uporabi vodij - dobrih ali slabih (Fairholm, 2015, str. 33-35).

V Slovarju slovenskega knjižnega jezika je vodenje opredeljeno kot glagolnik od voditi. Izmed množice pojasnil naj izpostavimo dve, in sicer: 1. z zgledom, nasveti delati, povzročati, da kdo ravna na določen način, in 2. delati, da kdo ravna v skladu z določenim ciljem (Slovar slovenskega knjižnega jezika, 2018, e-vir). Iz obeh navedenih opisov je mogoče sklepati, da je pri vodenju najpomembnejše vplivanje. Strinjamo s z Maxwellom, ki pravi, da je vodenje nič več in nič manj kot le vplivanje (Maxwell, 1993, str. 1).

V tesni povezavi s pojmom vodenje se uporablja tudi pojem voditeljstvo. Njegovo razlago prav tako najdemo v Slovarju slovenskega knjižnega jezika, ki ga povezuje z voditeljskim mestom oziroma položajem in z značilnostjo voditelja (Slovar slovenskega knjižnega jezika, 2018, e-vir). V primeru Slovenske vojske prevod pojma leadership pomeni prevzetje pojma voditeljstvo in kot pravi Jazbec, je to prineslo nekaj zagat v praksi (Jazbec, 2015, str. 36). Neprimernemu slovenskemu prevodu pojma leadership pritrjuje tudi Društvo slovenska akademija za management, ki kot dopusten prevod navaja pojma vodenje in vodstvo ter označuje voditeljstvo za neprimernega (Angleško-slovenski slovar izrazov s področij ravnateljevanja (angl. management) in sorodnih področij, 2018, e-vir). Za poenotenje terminologije in da bi se ognili zagatam v nadaljevanju, bomo v tem prispevku uporabljali le termin vodenje oziroma vodja, ker ne glede na to, ali je posameznik na formalnem mestu vodje ali ga sodelavci prepoznajo kot neformalnega vodjo, s svojim vplivanjem, delovanjem, zgledom ... vodi. Glagolnik od voditi je pa vodenje in ne voditeljstvo.

Kot pravi Zupančič, je že Sun Tzu povedal, da je poveljnik tisti, ki je odgovoren za ljudi in usodo svoje domovine (Zupančič, 1996, str. 38). Poveljnik je formalni vodja, katerega pristojnosti in odgovornosti so določene $\mathrm{z}$ zakonom in podzakonskimi akti. Poveljnik oziroma vodja si mora s svojim vodenjem pridobiti spoštovanje in zaupanje svojih podrejenih, da mu bodo sledili v dobrem in slabem. Seveda so tu še neformalni vodje, ki nimajo moči formalnega položaja, ampak so med sebi enakimi prepoznani, da imajo sposobnosti vodje. Zaželeno je, da je formalni vodja hkrati tudi neformalni. To pa zahteva veliko napora, učenja in izkušenj. Račnik povzema zelo zanimivo Maxwellovo ugotovitev, ki pravi: »Kdor je vodja že 10 let in medtem ni šel na kakšno izobraževanje za vodje, ne bere knjig in strokovne literature s področja psihologije vodenja, ne dela na sebi, ima dejansko samo pol leta delovnih izkušenj na področju vodstvenih veščin, ki jih je že 20-krat ponovil« (Maxwell v: Račnik, 2010, str. 15). 


\subsection{Vojaško vodenje}

Vojaška doktrina SV opredeljuje vojaško vodenje kot pomemben element bojne morale, s katero se izkazujejo zavzetost, vztrajnost in pripravljenost za odrekanje ter sprejemanje žrtev in tveganja pri izpolnjevanju poslanstva enote (Furlan et al., 2006, str. 17).

Kark, Presler in Tubi opredeljujejo vodenje kot kontekstualni pojav oziroma fenomen, ki se nenehno razvija, spreminja in uporablja v različnih okoljih. Je del vsake organizacije. Na vodenje vplivajo poslanstvo organizacije, delegacija pristojnosti in odgovornosti, organizacijska struktura in kultura. Skladno s tem je vojaško vodenje tako teoretična kot praktična disciplina, izhajajoča iz civilnega vodenja, in vključuje tako generične kot edinstvene kontekstne elemente (Kark, Presler, Tubi, 2016, str. 161).

Kark, Presler in Tubi opisujejo različne značilnosti vojaškega vodenja. Okvir, ki oblikuje vojaško vodenje, je predvsem najpomembnejša naloga vojaške organizacije - ohranjanje varnosti, zato imajo pripadniki vojske legitimnost uporabe sile, kadar je to potrebno. Pri tem gre za skrajni kontekst, za katerega sta značilni nevarnost in potencialna psihološka, fizična ali materialna škoda. Čeprav te ekstremne situacije ne simbolizirajo vseh vojaških poklicev in vojaških enot, njene simbolične in strukturne posledice veljajo za celotno vojaško organizacijo in vojaško vodenje na splošno. Druge posebne značilnosti, ki vplivajo na vojaško vodenje in ga oblikujejo, izhajajo iz varnostnih in bojnih nalog v vojaški organizaciji. Za vojaške organizacije je značilna njihova totaliteta, ki nadzira skoraj vsak vidik življenja svojih pripadnikov. Posledično je odvisnost pripadnikov od vodje večja kot v drugih (nevojaških) institucijah. Druga glavna značilnost vojske je v njeni formalni institucionalni strukturi. Vojske si prizadevajo doseči svoje cilje prek organiziranih poveljstev in enot na hierarhični način. To pomeni, da je poveljnik osrednji lik točno določene hierarhije in da struktura moči v vojski, ki oblikuje stile in načine vodenja, večinoma temelji na činu in liniji poveljevanja. Naslednji pomemben vidik, ki definira vojaško vodenje, je velikost vojske oziroma velika številčnost njenih pripadnikov. Obseg vojaških organizacij nujno pripelje do položaja, v katerem vsaka odločitev in povelje, ki so ga izdali poveljniki, neposredno vpliva na veliko število podrejenih. To predstavlja svojevrstne izzive in stres za vodje, ki morajo v danem trenutku sprejemati odločitve in jih razumljivo posredovati svojim podrejenim. Izvrševanje ukazov je temeljni pogoj za uspešno delovanje v vojski. Velik obseg vojske prispeva tudi k potrebi po neprekinjenem ohranjanju discipline, poveljevanju in krepitvi hierarhične strukture in hierarhičnega vodenja. Iz tega izhaja še ena posebna značilnost vojaškega vodenja - prepoznavanje vodenja kot ključne sposobnosti v vojaški organizaciji oziroma ko je vodenje učinkovito, lahko vojaška organizacija deluje osredotočeno in sinhronizirano, z učinkovito porabo virov in zmožnostjo doseči želene rezultate. Za celovito razumevanje vojaškega vodenja je poleg organiziranja treba razumeti tudi čas, v katerem vojaško vodenje trenutno deluje, spremembe na področjih delovanja, pa tudi pomembne družbene, kulturne in tehnološke spremembe, ki ga oblikujejo. V osemdesetih in zgodnjih devetdesetih letih prejšnjega stoletja je bil 
konec hladne vojne vzrok, da se je strateška vojaška stvarnost v celoti preoblikovala, saj so vojaške organizacije prisiljene obvladovati različne in pogosto spreminjajoče se grožnje. V današnjem času morajo vojaki delovati v celotnem spektru operacij, kar pomeni, da vojaška enota lahko na primer deluje v urbanem okolju ali načrtuje zasedo, nato se pa uro pozneje spoprijema z zagotavljanjem humanitarne pomoči. Skratka, srečujejo se s t. i. hibridnimi grožnjami, ki so posebne, kajti čeprav imajo te grožnje široko svetovno razsežnost, so temeljito vključene v lokalno prebivalstvo, v katerem danes delujejo oborožene sile, in zahtevajo medsebojno sodelovanje $\mathrm{z}$ lokalnimi, civilnimi ter vojaškimi silami. Globalna razsežnost pride še dodatno do izraza ob delovanju množičnih medijev, ki prek najrazličnejših kanalov in socialnih omrežij vplivajo na politiko in tudi na različne mednarodne institucije. Vojaški vodje se morajo najpogosteje v trenutku odločiti in posledice takih odločitev imajo lahko uničujoče učinke na že vzpostavljena razmerja in odnose s civilno populacijo ali pa celo povzročijo mednarodne incidente s hudimi posledicami (Kark, Presler, Tubi, 2016, str. 161-163). Ti vodje so lahko na zelo nizki ravni v vojaški hierarhiji in že leta 1999 je ameriški general Charles C. Krulak uvedel izraz strateški desetnik (strategic corporal) in v svojem prispevku z naslovom The Strategic Corporal: Leadership in the Three Block War podrobno opisal razsežnosti odločitev desetnika Hernandeza na eni od operacij v osrednji Afriki (Krulak, 1999, str. 16-21).

Nikakor ne smemo pozabiti, da lahko prav vsak vojak s svojim dejanjem povzroči strateške učinke in vodje se morajo tega dobro zavedati.

Na koncu je treba povedati, da se pri vojaškem vodenju odloča o človeških življenjih - življenjih pripadnikov lastnih enot in tudi nasprotnikov oziroma sovražnikov.

\subsection{Sodobni izzivi vodenja}

Vodenje je $\mathrm{v}$ nenehno spreminjajočem se okolju odvisno od sprememb in izzivov. Zagotovo imajo močan vpliv način razmišljanja novih, mlajših generacij, spreminjanje družbenih vrednotnih sistemov, spremenjeno varnostno okolje in tehnološki napredek. Teh trendov ni mogoče obravnavati kot ločena vprašanja. Njihovi soodvisni učinki bodo še naprej močno vplivali na vse oborožene sile, kulturo organizacije in tudi na to, kako se kaže vodenje posameznikov in organizacij. Izzivi so bili in bodo tudi v prihodnosti. Kljub družbenim spremembam in izzivom na področju vodenja se potreba po vojaških vodjih z močnimi osebnostnimi lastnostmi - značajem, integriteto in etiko - ne bo spremenila. V nasprotju z Brecljem in njegovo opredelitvijo sodobnih izzivov vojaškega vodenja (uveljavljanje vrednot; kohezija v vojaških enotah; motivacija vodenih; oblikovanje enote; razvijanje osebnostnih lastnosti; komunikacija s podrejenimi; pridobivanje, vzdrževanje in razvoj kompetenc; nove filozofije vodenja in poveljevanja - poveljevanje na podlagi poslanstva itn.) (Brecelj, 2007, str. 47) bomo opredelili le tri sodobne izzive, katerih (ne)razumevanje in vedno večje pojavljanje $\mathrm{v}$ praksi lahko pomeni pomembno prednost za vsakega vodjo pri vodenju. Namen tega poglavja ni podrobna razčlenitev teh treh izzivov, temveč le osvetlitev nekaterih opredelitev, zaradi katerih je treba 
tem izzivom že zdaj in tudi v prihodnje nameniti več pozornosti in obravnave. Se pa strinjamo z Brecljem, da je mogoče sodobne izzive vodenja deliti na več načinov glede na ravni voditeljstva, na vrsto okolja in vrsto operacij, na dejavnike voditeljstva ter glede na splošno opredelitev izzivov sodobnega vojaškega voditeljstva (prav tam).

Sodobni izzivi, ki jih bomo za potrebe tega članka opredelili, so:

- sledenje,

- toksično vodenje,

- ženske kot vodje.

\subsubsection{Sledenje}

Sledenje je enako pomembna vloga kot vodenje. Je vloga, ki jo je treba prevzeti na določenem mestu in času. Tako v življenju kot v vojski je zelo malo priložnosti za vodenje - da si edini nosilec odločanja, vizije, usmerjanja in odgovornosti. Najpogosteje je še vedno nekdo, ki je v podporni vlogi odločevalca. Ta oseba je sledilec. In kot se pri vodenju uporablja termin voditeljstvo, se tudi pri sledenju enakovredno uporablja termin slediteljstvo. Menimo, da ta terminologija ni pravilna, saj je glagolnik od slediti sledenje in ne slediteljstvo ali sledilstvo. ${ }^{1}$

Glede na trditev iz začetka tega podpoglavja bi pričakovali, da bo sledenje enako odmevno kot vodenje. Vendar je še vedno več pozornosti in proučevanja namenjenega vodenju kot sledenju. Treba je razumeti, da smo v vojski, tudi kadar smo na vodilnih položajih, vsi sledilci. Vodje na svoji poti ne smejo pozabiti na uporabo lastnosti in spretnosti, ki so se jih naučili kot dobri sledilci. Tako kot se od sledilcev pričakuje, da se bodo učili od vodij, mora enako veljati tudi v nasprotni smeri. Vodje, ki se učijo od sledilcev, postanejo učinkovitejši vodje.

Tako kot imajo dobri vodje svoje univerzalne dobre lastnosti, velja enako tudi za dobre sledilce. John S. McCallum v svojem članku navaja naslednje odlike dobrih sledilcev:

- razsodnost,

- delovna etika,

- kompetentnost,

- poštenost,

- pogum,

- diskretnost,

- lojalnost,

- upravljanje ega (McCallum, 2013, str. 6-9).

1 Besed slediteljstvo in sledilstvo Slovar slovenskega knjižnega jezika ne opredeljuje. 
Vojaški vodje lahko pričakujejo, da bodo vodili enote, katerih posamezniki imajo različne stile sledenja in celo predstavljajo različne stile v različnih okoliščinah. Vojaški vodje si morajo prizadevati, da vse svoje podrejene razvijejo v učinkovite sledilce in hkrati delujejo skladno $\mathrm{z}$ vrednotami.

Kot pravi Sharma, je dobro vodenje pogoj za privrženost ljudi. Ko bodo sledilci ugotovili, da se vodja zavzema za njihove interese, mu bodo začeli slediti. Tako si bo vodja pridobil tisto najpomembnejše - njihovo zaupanje. Sledilcem je treba dati izzive in jim dovoliti, da rastejo. Zagotovo jim bo od časa do časa spodletelo, vendar se iz tega naučijo zmagati - zmaga je hitra pot do uspeha. Vodja mora svoje sledilce spodbujati, ne pa jih ovirati. Vodja bo samo toliko uspešen, kolikor bodo uspešni njegovi sledilci (Sharma, 2017, str. 82-88).

Upamo si trditi, da le dobri sledilci lahko postanejo uspešni vodje.

Glede na pomembnost razumevanja koncepta sledenja bi pričakovali, da bo ta vsebina v vojaškem izobraževanju in usposabljanju zastopana enako kot vsebine o vodenju. Ugotovili smo, da se v času nastajanja tega članka sledenje kot vsebina v programih vojaškega izobraževanja in usposabljanja pripadnikov SV praktično ne pojavlja. Zaslediti jo je mogoče le v programu višjega tečaja za podčastnike in še to le kot eno od štirih učnih vprašanj pri temi Vojaško voditeljstvo in vodenje podrejenih, za katero je namenjenih dve uri predavanj in ena ura samostojnega dela slušateljev (Program višjega tečaja za podčastnike, 2015, str. 16).

Za uspešno spoprijemanje s sodobnim izzivom vodenja in zaradi povečanja učinkovitosti vodenja v SV je veliko več pozornosti treba nameniti poučevanju pripadnikov SV o sledenju in sledilcih. Ob naslednji evalvaciji in prenovi programov vojaškega izobraževanja in usposabljanja ( $\mathrm{v}$ nadaljevanju VIU) predlagamo vključitev teh vsebin v vse programe t. i. kariernih tečajev, saj bodo le tako pripadniki dobili potrebna znanja na institucionalni ravni.

\subsubsection{Toksično vodenje}

Standardne opredelitve toksičnosti v kontekstu vodenja ni, saj so razumevanja o vedenju vodje oziroma nadrejenega subjektivna. Ker večina organizacijskih kultur $\mathrm{V}$ vojskah, podjetjih in politiki poudarja lojalnost vodji in ker je stopnja krutosti prisotna pri nekaterih visoko cenjenih vodjih tako v oboroženih silah, gospodarstvu in tudi politiki, je število toksičnih vodij v posamezni organizaciji lahko le približna ocena.

Doktrina vojaškega vodenja ameriške vojske, Army Doctrine Publication - ADP 6-22 Army Leadership, opredeljuje toksično vodenje kot eno od oblik negativnega vodenja. Toksično vodenje je kombinacija egocentričnih odnosov, motivacij in vedenj, ki imajo negativne učinke na sledilce, organizacijo in uspešnost realizacije nalog. Tak vodja nima občutka za druge ali za organizacijsko klimo, kar pripelje do kratkoročnih in dolgoročnih negativnih učinkov. Toksični vodja deluje z 
napihnjenim občutkom lastne večvrednosti in akutne sebičnosti. Toksični vodje dosledno uporabljajo disfunkcionalno vedenje, da zavajajo, ustrahujejo, prisilijo ali nepošteno kaznujejo druge, da bi dobili tisto, kar si želijo zase (ADP 6-22 Army Leadership, 2012, str. 3).

V Britanski kopenski vojski so že leta 2009 razkrili, da imajo težave zaradi toksičnih vodij in sistemskih napak višjih častnikov (Harding, 2009, str. 14-16).

Draksler v svoji diplomski nalogi opredeli toksično vodenje kot »/.../ destruktivno, škodljivo obliko vodenja, ki osebam, podvrženim tej obliki vodenja, povzroča karierno in osebno škodo, krivice, občutek zapostavljenosti ali celo kršenje človekovih pravic. Enota, podvržena taki obliki vodenja, trpi moralno krizo, neučinkovitost in zastoj v razvoju ter okrnjeno raven pripravljenosti. Toksični vodja je oseba, ki izvaja toksično vodenje iz sebičnih vzgibov za potrebe lastne promocije in kariere na škodo podrejenih in enote. Njegov stil vodenja je škodljiv in ustvarja pogoje za nezdravo vzdušje« (Draksler, 2015, str. 13).

Lahko bi rekli, da toksične vodje zaznamujejo egoizem, materializem, premetenost, neetične odločitve in kontraproduktivno vedenje na delovnem mestu, prestopništvo in pomanjkanje integritete. Njihove odločitve so sebične, maščevalne, goljufive in lažnive.

Najpomembnejši prvi korak pri prepoznavanju toksičnega vodenja je prepoznavanje vedenja, značilnosti in simptomov. Kot navaja J. E. Box v svojem raziskovalnem projektu Toxic Leadership in the Military Profession, lahko toksičnega vodjo prepoznamo po naslednjih vedenjih ali lastnostih:

- mikromenedžer,

- pretendent,

- egocentrik (Box, 2012, str. 6-9).

Toksično vodenje in visoka raven samozavesti takega vodje se lahko hitro napačno razume in obravnava kot močno in pozitivno vodenje. Vendar vodenje ni tekmovanje v priljubljenosti. Temelj vodenja so ljudje. Ljudje bodo najverjetneje sledili nekomu, ki jim je všeč in ga spoštujejo.

SV se očitno spopada s krizo vodenja, kar dokazujejo tudi rezultati raziskave percepcije in motivacije $\mathrm{v}$ desetletnem obdobju profesionalizacije, ki je bila narejena leta 2014. Z vidika vodenja je zaskrbljujoče, da so anketiranci izrazito negativno ocenili: zaupanje pripadnikov v SV in poveljujoče, ustrezno vodenje in odnose, poštenost in pravičnost, način vodenja, ki upošteva vsakega od zaposlenih, pohvale za opravljeno delo, ustrezno obveščanje, spodbujanje k osebnim dosežkom pri delu, vsebino dela, ki jo je treba opraviti, sprejemanje odgovornosti za opravljeno delo, priznanja in pohvale ter najbolj negativno zaznan element motivacije - napredovanje in priznavanje delovnih izkušenj in znanja, zmanjševanje občutka, da se vloga 
posameznika v sistemu, njegovo znanje in izkušnje, ne cenijo dovolj (Rupar, 2014, str. 36-41).

Na krizo vodenja v SV, predvsem z vidika zaznavanja toksičnega vodenja, opozarja tudi Kalič, ki pravi, da se neželeno voditeljstvo $\mathrm{v}$ realnosti pojavlja $\mathrm{v}$ različnih pojavnih oblikah, kar podkrepi z izjavami intervjuvancev, ki so sodelovali $\mathrm{v}$ intervjuju ob pisanju njegove zaključne naloge. Strinjamo se z njegovo navedbo, da se »SV v preteklih nekaj letih sooča z izrazito neugodnimi vplivi, ki ne omogočajo optimalnega okolja za razvoj dobrega voditeljstva. Zato se je organizacijska kultura deformirala in na površje je prišlo kar nekaj pojavov neželenega voditeljstva. Deformirana organizacijska kultura ustvarja nove toksične poveljnike in ti nadaljujejo deformacijo organizacijske kulture« (Kalič, 2018, str. 51-53).

Glede na vedno večjo krizo vodenja v SV in javna razkritja imen toksičnih vodij in $\mathrm{s}$ tem povezanih odpustov $\mathrm{v}$ ameriški in britanski vojski bi bilo pričakovati, da bo ta vsebina našla svoje mesto v vojaškem izobraževanju in usposabljanju v SV. Ugotovili smo, da se vsebine o toksičnem vodenju v programih vojaškega izobraževanja in usposabljanja pripadnikov SV ne pojavljajo.

Za uspešno spoprijemanje s tem sodobnim izzivom vodenja in zaradi povečanja učinkovitosti vodenja v SV je treba nameniti veliko več pozornosti celovitemu ozaveščanju pripadnikov SV o toksičnem vodenju, kar vključuje odkrite pogovore v obliki okroglih miz in tudi spodbujanje za pisanje strokovnih člankov. Ob naslednji evalvaciji in prenovi programov VIU predlagamo vključitev teh vsebin v vse programe t. i. kariernih tečajev, saj bodo le tako pripadniki SV dobili potrebna znanja na institucionalni ravni.

\subsection{3 Ženske kot vodje}

$\mathrm{V}$ primerjavi z moškimi vodji je referenčna točka za dobro vodenje nezadostno opredeljena za ženske vodje. Tradicionalne in konkretno opredeljene vloge spolov v družbi so vplivale tudi na raziskave in ugotovitve ${ }^{2}$ o vlogi žensk kot vodij — vlogi, ki je ločena od stereotipnih vlog žensk. Tako je bilo za žensko že precej težko doseči najprej položaj vodje, nato pa se je morala boriti še za sprejem in vključenost kot vodja. Ironično je, da je bila tako v konservativnih kot liberalnih kulturah prisotnost žensk na vplivnih položajih, položajih moči in vodstvenih položajih vse prej kot zaželena. Toda tudi ta stereotip se spreminja tako v gospodarstvu kot negospodarstvu. Vojska ni nobena izjema. Ženske simbolizirajo enotnost in sodelovanje. So ključnega pomena za preživetje. Ženske se nenehno razvijajo in dosegajo nove mejnike v širokem spektru človeških dejavnosti v sodobnem času.

\footnotetext{
Glej »A Global Look at Psychological Barriers to Women `s Progress in Management«. Journal of Social Issues, 57(4), str. 675-688 ter Prime, J. L. in Carter, T. M. (2009). Women »Take Care, « Men »Take Charge«: Managers `Stereotypic Perceptions of Women and Men Leaders. The Psychologist-Manager Journal, 12, str. $25-49$.
} 
Pomembnost žensk kot vodij se kaže predvsem v opredelitvah, ki so različne od moških vodij. Navajamo le nekatere, ki so opisane v prispevku Women in Leadership. Ženske vodje uporabljajo predvsem transformacijski stil vodenja $\mathrm{v}$ primerjavi $\mathrm{z}$ moškim vodjem in delujejo kot vzor za svoje podrejene. Navdihujejo svoje sledilce in namenijo veliko časa njihovemu mentoriranju in osebnostnemu razvoju. Ženske vodje poudarjajo timsko delo in verodostojno komunikacijo kot ključ do uspeha. Za večino ženskih vodij vodenje ni namenjeno le doseganju organizacijskih ciljev, temveč transformaciji svojih sledilcev v boljše ljudi. Ženske vodje se vedno osredotočajo na dokončanje nalog $\mathrm{v}$ določenih rokih. $\mathrm{Z}$ operativnega vidika je pravočasno zaključevanje dnevnih nalog zelo pomembno, da se zagotovi nemoteno delovanje organizacijske enote. Sodelovalno delo z drugimi je tipična ženstvena značilnost. Ženske vodje vedno spodbujajo sodelovanje in interakcijo med sledilci. Pomembno je, da vsi sledilci jasno razumejo svoje vloge in odgovornosti, sicer lahko to pripelje do odvečnega dela. Ženske vodje so pogosto participativne in imajo demokratičen stil vodenja. Zdi se, da prezrejo stil poveljevanja in kontrole, ki ga izvajajo moški vodje. Ženske pogosto posredno sporočajo svoja pričakovanja glede določene naloge in omogočajo več manevrskega prostora pri doseganju cilja. Včasih to pomaga sledilcem bolje uporabiti svoje znanje in spretnosti za dokončanje naloge, vendar je to lahko tudi pomanjkljivost, če dodeljena naloga zahteva od vodje, da ima neposredno komunikacijo s sledilci. V primerjavi s svojimi moškimi kolegi se ženske vodje pogosto zdijo skromne ali tihe glede lastnih dosežkov. Pogosto so zadržane pri samopromociji. Vendar je zelo pomembno, da se ženske vodje naučijo, kako se promovirati s svojimi dosežki in rezultati. Če drugi ne vedo in ne opazijo, česa so zmožne, ne morejo prepoznati njihovih vodstvenih lastnosti. Ženske vodje so bolj nagnjene k pozitivnemu pogledu na dogodke in ves čas ostajajo optimistične. Zaradi te lastnosti ženske vodje ob mnogih priložnostih dosegajo boljše rezultate in razvoj dogodkov. Optimizem namreč vodi v razvoj zaupanja. Ženske vodje kažejo več samozavesti in zaupanje $v$ sledilce. To jim omogoča, da pridobijo podporo sledilcev, ki jim v zameno pomagajo pri doseganju uspehov (Women in Leadership, 2017, e-vir).

Ženske igrajo več vlog v družbi in so začele vstopati v nekdanje tipično rezervirane (vodstvene) vloge moških. Ženske vodje veliko prispevajo v organizacijah, ker mislijo in se vedejo drugače kot moški. Ugotavljamo, da imata oba spola pri vodenju svoje osebne prednosti. Moški uporabljajo več individualnih odločitvenih in kontrolnih korektivnih ukrepov, ženske pa več participativnega odločanja in navdiha za sledilce.

Northouse navaja, da spodbujanje različnih skupin žensk v vloge vodij ne bodo le pripomogle $\mathrm{k}$ bolj reprezentativnim institucijam, podjetjem in vladam, temveč lahko prispevajo tudi $\mathrm{k}$ bolj etičnim, produktivnim, inovativnim in finančno uspešnim organizacijam, ki izkazujejo višje ravni kolektivne inteligence in so manj obremenjene s konflikti (Northouse, 2016, str. 409). 
Zanimivo, da je šele 25. oktobra 2018 britanski obrambni sekretar Gavin Williamson izjavil, da so od tega datuma naprej vse vojaške dolžnosti v Britanski kopenski vojski odprte tudi za ženske. ${ }^{3}$ Zelo pomembna pa je tudi izjava poveljnika Britanske kopenske vojske generala Patricka Sandersa, da je kar nekaj najboljših vojakov in obetavnih častnikov, ki jih pozna, prav žensk. Pravi tudi, da bo pehota v vojni učinkovitejša, če bodo v njej združeni najboljši talenti, ki jih premorejo v državi moški in ženske. ${ }^{4}$

Glede na vedno večji porast žensk v vlogah vodij, tudi v SV, bi bilo pričakovati, da bo tej vsebini v vojaškem izobraževanju in usposabljanju namenjene več pozornosti. Ugotovili smo, da programi vojaškega izobraževanja in usposabljanja pripadnikov SV vsebujejo le teme, povezane s človekovimi pravicami, upravljanjem različnosti (predvsem kulturne) in diskriminacije (vsesplošne). Konkretnih vsebin o prednostih ženskih vodij v programih ni, niti ni vsebin s t. i. Gender perspective $e^{5}$ v oboroženih silah, kar nalaga tudi Natova Bi-SC Direktiva $040-001^{6}$ o integraciji UN resolucije 1325. ${ }^{7}$ V Natovi Bi-SC Direktivi 040-001 je predstavljeno, da morajo vsi pripadniki Nata biti usposobljeni iz vsebin UN resolucije 1325 in z njo povezanimi resolucijami.

Za uspešno spoprijemanje s sodobnim izzivom vodenja in zaradi povečanja zavesti o koristih ženskih vodij v SV je treba veliko več pozornosti o tej tematiki nameniti poučevanju pripadnikov SV. Ob naslednji evalvaciji in prenovi programov VIU predlagamo vključitev teh vsebin v vse programe t. i. kariernih tečajev, saj bodo le tako pripadniki SV dobili potrebna znanja na institucionalni ravni.

\section{VODENJE V SLOVENSKI VOJSKI}

Vodenje v SV je večnivojski, kompleksen in predvsem nedorečen fenomen. Opredelimo ga lahko v širšem in ožjem smislu. Za namen tega članka bomo za vodenje v širšem smislu uporabljali termin vodenje organizacije, za vodenje v ožjem smislu pa termin vodenje posameznika. Prvi termin je bolj tesno povezan s pojmi, kot so usmerjanje, nadzor, odločanje, upravljanje itn. Drugi termin pa se navezuje na vplivanje, razvoj, treniranje, mentoriranje in kontrolo. Na podlagi navedenega je

\footnotetext{
Dosegljivo na https://www.army.mod.uk/news-and-events/news/2018/10/women-in-ground-close-combat-roles/.

4 Dosegljivo na https://www.army.mod.uk/news-and-events/news/2018/10/women-in-ground-close-combat-roles/.

5 Gender perspective - integracija načela enakosti spolov kot strategija za to, da skrbi in izkušnje žensk in moških postanejo celovita razsežnost oblikovanja, izvajanja, spremljanja in vrednotenja politik, programov in vojaških operacij (https://www.nato.int/cps/en/natohq/topics_101372.htm.).

6 Cilj te direktive je prevesti politično usmeritev in smernice za zagotovitev učinkovitega izvajanja Resolucije Varnostnega sveta Združenih narodov (RVSZN) 1325. Dosegljiva na https://www.nato.int/issues/women_ nato/2017/Bi-SCD_40-1_2Rev.pdf.

Resolucija 1325 je bila prvi formalni in pravni dokument Varnostnega sveta, ki je zahteval, da stranke $v$ konfliktu preprečijo kršitve pravic žensk, podprejo udeležbo žensk v mirovnih pogajanjih in obnovi po konfliktu ter zaščitijo ženske in dekleta pred spolnim nasiljem v oboroženih spopadih. Prav tako je kot prva resolucija Varnostnega sveta Združenih narodov izrecno omenila edinstven učinek konflikta na ženske (https:// en.wikipedia.org/wiki/United_Nations_Security_Council_Resolution_1325).
} 
pomembno, da posameznike vodimo in organizacijo upravljamo. Razlika je občutna in pomembna.

Zaradi velikega obsega nalog in pristojnosti vseh deležnikov pri vodenju SV se bomo v tem članku podrobneje posvetili ureditvi pristojnosti ministra za obrambo in vrhovnega poveljnika obrambnih sil.

Vodenje organizacije SV je določeno v Zakonu o obrambi in številnih drugih zakonskih in podzakonskih aktih. SV deluje znotraj Ministrstva za obrambo in Generalštab SV predstavlja organ v sestavi tega ministrstva.

42. člen Zakona o obrambi (v nadaljevanju ZObr) določa naslednje naloge in pristojnosti ministra za obrambo:

»(1) Minister prek generalštaba odreja potrebne razvojne, organizacijske, tehnične in druge ukrepe ter usmeritve, ki jih izvršujejo načelnik generalštaba in podrejeni poveljniki. Poveljniki so ministru odgovorni za izvajanje teh ukrepov in usmeritev prek svojih nadrejenih.

(2) Minister določa planiranje in opremljanje, vrsto oborožitve in druge vojaške opreme, ki jo uporablja vojska, organizacijo materialne in zdravstvene oskrbe, programe usposabljanja, vojaškostrokovno literaturo, izdaja strokovna navodila in ureja druga upravna in strokovna vprašanja organizacije ter dela vojske.

(3) Minister po predhodnem mnenju predsednika republike določa generalštabu praviloma letne usmeritve za načrtovanje operativnih, materialnih in organizacijskih priprav za uporabo vojske. $\ll^{8}$

Ugotavljamo, da je minister za obrambo kot politični funkcionar pomembna oseba pri vodenju vojaške organizacije in to dejavnost izvaja s predpisi in akti vodenja, kot so smernice, obvezne usmeritve, odredbe, pravila in navodila. Tako preoblikuje politične odločitve v operativne naloge vojaške organizacije. Posebej je določeno, da pravila službe, kot akt vodenja, izdaja vlada. Akti vodenja se izdajajo v pisni obliki in so obvezni za vse, na katere se nanašajo (ZObr, 46. člen).

V sistemu vodenja obrambe države in tudi vodenja organizacije se pojavljajo še državni zbor, vlada in predsednik republike.

Najmanjšo vlogo pri vodenju SV ima predsednik države. Le na predlog vlade lahko odloči o uporabi SV, uvedbi delovne in materialne dolžnosti ter splošni mobilizaciji v izrednem stanju, če se državni zbor ne more sestati. Na enak način lahko razglasi izredno ali vojno stanje in sprejema uredbe $\mathrm{z}$ zakonsko močjo, ki se nanašajo na obrambo (ZObr, 83. člen). Ne smemo pozabiti, da je predsednik države, skladno z

ZObr, 42. člen. 
Ustavo Republike Slovenije, vrhovni poveljnik obrambnih sil, kar je paradoksalno stanje, ki zahteva ustreznejšo ureditev pristojnosti in odgovornosti vrhovnega poveljnika obrambnih sil do SV.

Na dvoumno opredelitev pristojnosti vrhovnega poveljnika, pristojnosti vlade in ministrov, razmerja med njimi in odnose znotraj obrambnih sil pri vodenju, še posebej pa nadzorno funkcijo državnega zbora, določeno z ustavo, je argumentirano opozoril že prvi predsednik samostojne Republike Slovenije Milan Kučan leta 1993. V pismu državnemu zboru je izrazil svoje mnenje o predlogu Zakona o obrambi in v več kot 20 konkretnih predlogih nedvoumno nakazal ustreznejšo zakonsko ureditev pristojnosti in odgovornosti vrhovnega poveljnika obrambnih sil, ministra, vlade in državnega zbora.

Med drugim je glede vodenja predlagal:

»Minister za obrambo naj po zakonski določbi uresničuje usmerjanje vojske z izdajanjem pravilnikov, navodil in drugih izvedbenih predpisov za izvajanje zakona ter z dajanjem usmeritev za razvoj, opremljanje, priprave, materialno in finančno poslovanje in za druge zadeve iz svoje pristojnosti. Zakon naj določi, da predsednik republike kot vrhovni poveljnik lahko prenese določene zadeve vodenja na ministra za obrambo. Tudi taka ureditev bi se razlikovala od sedaj predloženega zakona, ki vodenje v celoti prenaša na ministra za obrambo. Po sedanji ureditvi je bilo mogoče prenesti določene zadeve vodenja, ne pa tudi poveljevanja, na ministra za obrambo in je to predsedstvo republike tudi storilo« (Mnenje predsednika republike in vrhovnega poveljnika o predlogu zakona o obrambi, e-vir).

Tudi iz njegove argumentacije je mogoče potrditi ugotovitev, da je vodenje organizacije (SV) v celoti preneseno na ministra za obrambo, ki to izvaja s predpisi in akti vodenja. Kljub nekajkratnemu noveliranju ZObr te neustrezne zakonske ureditve niso bile urejene v luči predlogov takratnega predsednika države. Med drugim na neustrezno zakonsko ureditev na področju vodenja vojske opozarja tudi Obrulj v svoji doktorski disertaciji (Sodobni vidiki inšpekcijskega nadzora na obrambnem področju, Obrulj, 2014).

Ko govorimo o vodenju posameznika v vojaški organizaciji, se poleg zavednega in nezavednega vplivanja srečamo s posebno obliko vodenja, in sicer s poveljevanjem.

\subsection{Poveljevanje}

V praksi se pogosto mešata besedni zvezi vodenje in poveljevanje ter poveljevanje in kontrola. Kot navaja Obrulj, je koncept vodenja in poveljevanja po osamosvojitvi izhajal iz vojaškega sistema Teritorialne obrambe. »Vodenje je predstavljalo organizirano dejavnost, ki je sestavljena iz neprekinjenih priprav, organiziranja in kontrole izvajanja aktivnosti z namenom, da dosežemo svoj cilj. Poveljevanje je bila posebna oblika vodenja, ki se uporablja na področju vojaških dejavnosti, in se je kazalo v: 
- koncentraciji pravic ene osebe pri odločanju (poveljnik),

- specifičnem načinu delovanja in obnašanja $\mathrm{V}$ medsebojnih odnosih (nadrejeni - podrejeni, ukazi),

- osebni odgovornosti za dejanja (moralno, materialno, kazensko).

Načela vodenja in poveljevanja so bila: enotnost, trajnost, dinamičnost, prožnost, učinkovitost, varnost« (Obrulj, 2014, str. 86).

Tako kot vodenje, se tudi za poveljevanje uporablja širši in ožji kontekst.

»V širšem smislu razumemo s poveljevanjem obliko vodenja, ki je prisotna v tistih organizacijah, v katerih obstaja med nadrejenimi in podrejenim poveljniški odnos. Gre za posebni model vodenja, ki se uporablja v razmerah, ki zahtevajo visoko stopnjo striktnosti. Tipična organizacija, v kateri je prisotno poveljevanje v širšem smislu, so oborožene sile oziroma vojaška organizacija, zato je termin poveljevanje, razumljen v širšem smislu, sopomenka za termin vojaško vodenje in management.

$\mathrm{V}$ ožjem smislu pa razumemo s poveljevanjem fazo procesa vodenja, ki sledi organiziranju in s katero se dodeljujejo naloge podrejenim. Tudi v tem primeru se termin poveljevanje uporablja predvsem v zvezi z vojaškim okoljem, zato je poveljevanje faza vojaškega vodenja in kot termin sopomenka za ukazovanje« (Lubi v Obrulj, 2014, str. 87).

Vojaška doktrina opredeljuje poveljevanje kot pristojnost, ki jo imajo poveljniki na podlagi zakona. Obsega pa načrtovanje, organiziranje, vodenje in kontrolo dodeljenih sil. Poveljevanje uvršča v eno izmed sedmih bojnih funkcij in kot temeljno načelo postavlja enotnost poveljevanja. To pomeni, da je samo en poveljnik tisti, ki je pristojen in odgovoren (Furlan et al., 2006, str. 63-64).

Greene opozarja na nevarnost deljenega poveljevanja v nekaj zgodovinskih primerih. Tako je na primer Hanibal porazil Rimljane v bitki pri Kanah. Poleg uporabe nove formacije svojih enot (v obliki polmeseca) je Hanibal dobro vedel, da imajo Rimljani težave pri poveljevanju. Namreč, poveljevanje nad rimsko vojsko sta si delila dva tribunala, ki se nista mogla zediniti glede načina spopada s Hanibalovo vojsko. Posledice so bile katastrofalne. Naslednji primer je skoraj dva tisoč let pozneje, ko je pruski kralj in vojskovodja Friderik Veliki uspešno zmagoval v sedemletni vojni deloma tudi zato, ker je sprejemal odločitve veliko hitreje kot generali na nasprotni strani, saj so se morali o vsem prej posvetovati. Tudi v vietnamski vojni je enotnost poveljevanja, ki jo je uveljavljal severnovietnamski general Vo Nguyen Giap, pomenila veliko prednost pred ameriškimi silami, katerih strategije in ukaze so ustvarjale množice politikov in generalov. Za podkrepitev pomembnosti enotnosti poveljevanja pritrjuje Napoleonov rek, da je boljši en slab general kot dva dobra (Greene, 2006, str.186-187). 
Poveljevanje v SV je določeno v Zakonu o obrambi in drugih zakonskih in podzakonskih aktih. Zakon o obrambi določa temeljna načela poveljevanja $\mathrm{v}$ SV. Tako je za najvišji vojaški strokovni organ za poveljevanje z vojsko določen Generalštab SV (ZObr, 39. člen).

Poveljevanje v SV se izvaja z akti poveljevanja, kot so direktive, odločitve, načrti, ukazi ali povelja. Vsi akti, razen povelj, se praviloma izdajajo v pisni obliki (ZObr, 46. člen).

Poveljevanje v SV izvajajo poveljniki z akti poveljevanja. Pravila službe v SV opredeljujejo, da je poveljnik vojaška oseba, ki opravlja poveljniško dolžnost in ima pristojnost poveljevanja. Prav tako imajo pristojnost poveljevanja vojaške osebe na vodstvenih položajih v poveljstvih, enotah in zavodih (Pravila službe v SV, 8. točka).

Pomembno vlogo pri poveljevanju ima vojaška disciplina, ki pomeni »/.../ brezpogojno, natančno, pravilno in pravočasno izpolnjevanje vojaških dolžnosti $\mathrm{v}$ skladu s predpisi, pravili službe ter akti vodenja in poveljevanja« (Pravila službe v SV, 7. točka). Disciplina je naučeno vedenje in je veliko več kot le slepa poslušnost. Uspešen vodja je tisti, ki doseže, da njegovi podrejeni disciplino ponotranjijo in se ji ne podrejajo samo zaradi strahu pred avtoriteto. Tako bodo vojaki ohranjali red in povezanost med seboj tudi takrat, ko njihov nadrejeni ne bo prisoten. Disciplina pomeni postavljanje naloge enote pred lastne želje. Disciplina je bistven del bojevniškega etosa. Če vojaška disciplina in reševanje problemov v okviru sistema poveljevanja in kontrole ne potekata pravočasno ter enotno, se začnejo poveljujoči pri vsakodnevnem poveljevanju in kontroli srečevati z nezaupanjem, ki vpliva na tveganje in varnost.

Strinjamo se z Obruljem, ki navaja, da se z vojaško disciplino vzpostavi urejen sistem sporazumevanja, določijo se pravila, kaj je dopustno in kaj nedopustno vedenje, oblikuje se delovna klima in z njo morala. Ob vzpostavljeni ustrezni vojaški disciplini se zagotovijo zadovoljstvo med pripadniki in varno ter dosledno opravljanje nalog. Treba se je zavedati, da v vojski neupoštevanje vojaške discipline lahko pomeni razliko med življenjem in smrtjo (Obrulj, 2011, str. 52-53).

Ugotavljamo, da so poveljniška razmerja od načelnika Generalštaba SV do podrejenih poveljnikov ustrezno urejena, se pa zagotovo pojavlja dvom o ustrezno urejenem razmerju vrhovnega poveljnika do načelnika Generalštaba SV oziroma nasploh o pristojnostih in odgovornostih vrhovnega poveljnika - podobno, kot smo navajali $\mathrm{v}$ poglavju o vodenju. Po ustavi je predsednik republike vrhovni poveljnik obrambnih sil, kar pomeni, da poveljuje oboroženim silam. Vrhovni poveljnik je odgovoren ne le za tisto, kar je storil, ampak tudi za tisto, kar je opustil, kar ni preprečil. V tem trenutku zakonsko določene pristojnosti na področju obrambe ne uresničujejo ustavne funkcije vrhovnega poveljnika z vidika zagotavljanja podrejenosti vojske civilni državi, preglednosti odnosov med državo in njenimi organi, to je med državnim zborom, vlado, ministrom za obrambo, predsednikom republike in vojsko. 
Strinjamo se z Ribaričem, ki v Komentarju ustave RS navaja, da poveljevalna veriga od vrhovnega poveljnika navzdol ni opredeljena. Ker je po ustavi predsednik republike odgovoren za opravljanje svoje funkcije v celoti, je zaradi take zakonske (ne)ureditve funkcije vrhovnega poveljnika odprto vprašanje odgovornosti predsednika republike kot vrhovnega poveljnika (KURS, str. 827).

Nedorečenost pristojnosti vrhovnega poveljnika ${ }^{9}$ je izpostavil tudi aktualni predsednik republike Borut Pahor v enem izmed intervjujev v času volilne kampanje. Jasno je povedal, da pristojnosti v zakonu niso razčiščene. Ugotavlja, da bi predvsem v vojni te ustavne (in zakonske) nejasnosti povzročile veliko škodo (Pahor vs. Šarec: Kaj bi dodala in kaj odvzela funkciji predsednika republike?, e-vir).

Po vstopu Slovenije v zvezo Nato $^{10}$ se namesto koncepta vodenja in poveljevanja začne uporabljati koncept poveljevanje in kontrola. Gre za dve med seboj tesno povezani funkciji, ki poveljniku omogočata usmerjanje in nadzor delovanja podrejenih poveljstev in enot. Poveljniki ne morejo učinkovito izvajati poveljevanja brez kontrole. Nasprotno pa kontrola nima funkcije brez poveljevanja, saj jo ta osredotoča. Poveljevanje in kontrola sestavljata nedeljiv sistem, katerega osnovni cilj je uspešno opravljena naloga. Vojaška doktrina opredeljuje sistem poveljevanja in kontrole ${ }^{11}$ (Command and Control-C2) kot sistem, ki poveljniku omogoča pravočasno in pravilno odločanje, dodeljevanje virov in nalog, usklajevanje bojnih funkcij ter vodenje in kontrolo delovanja s katere koli točke na bojišču (Furlan et al., 2006, str. 63).

Poveljevanje in kontrola ni le enosmerni proces, ampak gre za večsmerno delovanje in komuniciranje, saj na poveljnika vplivajo tako nadrejeni in sodelavci na isti ravni kakor tudi podrejeni s povratnimi informacijami. Tako, kot se stili vodenja gibajo od zelo avtoritativnih do zelo demokratičnih, tudi poveljevanje na isti premici poteka od podrobnega poveljevanja (Detailed Command) do poveljevanja na podlagi poslanstva (Mission Command ${ }^{12}$ ).

Skladno s tehnološkim razvojem sofisticiranih sistemov in glede na namembnost določenih nalog, ki jih vojska lahko opravlja, se v praksi pojavljajo številni izpeljani izrazi, ki poudarjajo različne vidike, uporabo in poddomene sistema poveljevanja in kontrole.

\footnotetext{
9 Več v doktorski disertaciji Sodobni vidiki inšpekcijskega nadzora na obrambnem področju, Obrulj, 2014, in $v$ Mnenju predsednika republike in vrhovnega poveljnika o predlogu zakona o obrambi, http://www.bivsipredsednik.si/up-rs/2002-2007/bp-mk.nsf/dokumenti/03.12.1993-92-97.

${ }^{10}$ Nato definira poveljevanje in kontrolo v krovni doktrinarni publikaciji AJP 1-0.

"I V SV uporabljamo kratico PINK.

12 Več v Sodobni vojaški izzivi »Poveljevanje z namero in Slovenska vojska«.
} 
Sklep Prizadevanja na kadrovskem področju v SV je treba usmeriti v zagotavljanje kakovostnega in stabilnega vodenja ter kakovostnega izobraževanja. V prispevku smo pregledno in nedvoumno razložili pojem vodenje skupaj z vzroki, ki so in še vplivajo na razvoj in oblikovanje te pomembne prvine pri delu z ljudmi v vsaki organizaciji in vsakdanjem življenju. Menimo, da je glede terminološko nedvoumne opredelitve v SV treba namesto izraza voditeljstvo enotno uporabljati izraz vodenje (osebek je vodja in ne voditelj). Kot odločilno dejstvo v podporo tega rezultata raziskovanja navajamo, da je vodenje glagolnik od voditi in vodenje ni le položaj, temveč aktivnost. Drugi termin, ki smo ga opredelili, je sledenje (osebek je sledilec in ne sleditelj) - kot zrcalna podoba vodenja. Ugotavljamo, da so navedeni termini pomembni $\mathrm{z}$ vidika terminološke enotnosti tako pri poučevanju vsebinskega področja vodenja $\mathrm{v}$ vojaških šolah SV kot tudi pri uporabi v praksi v poveljstvih in enotah SV. Obravnavani trije sodobni izzivi vodenja so po našem mnenju tisti, ki zahtevajo veliko več pozornosti v procesu VIU in tudi v drugih, strokovnih, pristopih. Rezultati raziskovanja so pokazali, da se vsebine teh treh pomembnih sodobnih izzivov vodenja ne pojavljajo niti v programih VIU niti ne zasledimo objav strokovnih ali znanstvenih člankov, povezanih s to tematiko, v strokovnih publikacijah SV. Za uspešno spoprijemanje z obravnavanimi izzivi vodenja in zaradi povečanja učinkovitosti vodenja $\mathrm{V} S \mathrm{~V}$ je treba v programe kariernih tečajev vključiti vsebine, ki bodo vodjem na praktičnih primerih pokazale pozitivne in negativne segmente posameznega izziva. Strokovnjaki določenega področja morajo z objavo strokovnih člankov o teh izzivih bolj aktivno ozaveščati in posledično vplivati na vse pripadnike SV. Odkrito se je treba pogovarjati o razkritih primerih toksičnega vodenja v drugih vojskah in o izkušnjah pripadnikov SV, ki so tako obliko vodenja izkusili pri svojem delu. Okrogle mize, tematske delavnice, sestanki ipd. na vseh ravneh so odlična platforma za tovrstne debate in učenje iz izkušenj. Pomembni sta tudi ustrezna ureditev in vključenost vrhovnega poveljnika obrambnih sil, kot sta to opozorila že dva dosedanja predsednika republike. Že samo upoštevanje vsega naštetega bi pripomoglo $\mathrm{k}$ večji dorečenosti vodenja v SV. 
Literatura 1. Ahmed, A., 2016. A brief history of leadership through time. Virgin, https://www.virgin. com/entrepreneur/brief-history-leadership-through-time.

2. Arhar, F., et al., 2010. Komentar Ustave Republike Slovenije. Kranj: Fakulteta za državne in evropske študije.

3. Army Leadership, Army Doctrinal Publication 6-22. (2012). Washington DC: Headquarters, Department of the Army.

4. Box, J., 2012. Toxic Leadership in the Military Profession. Carlisle: U.S. Army War College.

5. Brecelj, B., 2007. Sodobni izzivi vojaškega voditeljstva. Diplomsko delo. Ljubljana: Fakulteta za družbene vede.

6. Brezovšek, M., in Kukovič, S., 2014. Javno vodenje: sodobni izzivi. Ljubljana: Fakulteta za družbene vede.

7. Draksler, A., 2015. Toksično vodenje v vojaški organizaciji. Diplomsko delo. Maribor: Višja prometna šola.

8. Fairholm, M., 2015. Defining Leadership. GWU Center for Excellence in Municipal Management.

9. Furlan, B., et al., 2006. Vojaška doktrina. Ljubljana: Defensor

10. Greene, R., 2006. The 33 Strategies Of War. ZDA: Penguin Group Inc.

11. Harding, T., 2009. Officer attacks Army's ,toxic leadership'. The Telegraph, Vol. 9, No. 1, str. 14-16.

12. Jazbec, G., 2015. Priročnik Psihologija vodenja: Razvoj vodenja in enote ter njeno delovanje na misiji. Ljubljana: Generalštab SV.

13. Kalič, F., 2018. Neželeni pojavi vojaškega voditeljstva-študija primera SV. Zaključna naloga. Maribor: Poveljniško štabna šola.

14. Kark, R., Presler, T., Tubi, S., 2016. Paradox and Challenges in Military Leadership. $V$ Leadership Lessons from Compelling Contexts (Monographs in Leadership and Management, št. 8) / Peus, C., Braun, S., Schyns, B. (ur.) Emerald Group Publishing Limited.

15. Krulak, C., 1999. The Strategic Corporal: Leadership in the Three Block War. Marines Magazine, Vol. 16, No. 2, str. 16-21.

16. Maxwell, J., 1993. Developing the leader within you. ZDA: Thomas Nelson Inc. Publishers.

17. McCallum, J., 2013. Followership: The other side of leadership. Ivey Business Journal, Vol. 9. No. 3, str. 6-9.

18. Mnenje predsednika republike in vrhovnega poveljnika o predlogu zakona o obrambi, http://www.bivsi-predsednik.si/up-rs/2002-2007/bp-mk.nsf/dokumenti/03.12.1993-92-97.

19. Northouse, G., 2016. Leadership: Theory and Practice (Seventh Edition), ZDA: Sage Publication, Inc.

20. Obrulj, V., 2014. Sodobni vidiki inšpekcijskega nadzora na obrambnem področju. Doktorska disertacija. Kranj: Fakulteta za državne in evropske študije.

21. Obrulj, V., 2011. Paradigma vodenja in poveljevanja pri uveljavljanju vojaške discipline. Sodobni vojaški izzivi, december 2011 - 13, št. 4, str. 48-66.

22. Pahor vs. Šarec: Kaj bi dodala in kaj odvzela funkciji predsednika republike?, 2017, RTVSLO, https://www.rtvslo.si/gremvolit2017/grem-volit/pahor-vs-sarec-kaj-bi-dodalain-kaj-odvzela-funkciji-predsednika-republike/436929.

23. Pravila službe v Slovenski vojski. Uradni list RS, št. 84/09.

24. Program višjega tečaja za podčastnike. MORS, številka 603-76/2016-8, z dne 6. 7. 2016.

25. Račnik, M., 2010. Postani najboljši vodja. Štore: Samozaložba.

26. Rupar, R., 2014. Raziskava percepcije in motivacije v desetletnem obdobju profesionalizacije. Slovenska vojska, št. 10, str. 24-39. 
27. Sharma, R., 2017. Modrost o vodenju meniha, ki je prodal svojega Ferrarija. Tržič: Učila International.

28. Sklepi strateškega pregleda obrambe. (2017). Slovenska vojska, št. 1, str. 21-32.

29. Slovar izrazov s področja managementa in sorodnih področij. Slovenska akademija za management, http://sam-d.si/izraz/leadership/.

30. Slovar slovenskega knjižnega jezika. Slovarji Inštituta za slovenski jezik Frana Ramovša ZRC SAZU, https://fran.si/133/sskj2-slovar-slovenskega-knjiznega-jezika-2/3714549/vodit elj? View $=1 \&$ Query $=$ voditelj.

31. Ustava RS (URS). Uradni list RS, št. 33/91-I, 42/97 - UZS68, 66/00 - UZ80, 24/03UZ3a, 47, 68, 69/04 - UZ14, 69/04 - UZ43, 69/04 - UZ50, 68/06 - UZ121,140,143, 47/13 - UZ148, 47/13 - UZ90,97,99 in 75/16 - UZ70a.

32. Zakon o obrambi (ZObr). Uradni list RS, št. 103/04 - uradno prečiščeno besedilo in 95/15.

33. Zakon o službi v Slovenski vojski (ZSSloV). Uradni list RS, št. 68/07 in 58/08 - ZSPJS-I.

34. Women in Leadership - intoduction. (2017). Tutorialspoint. https://www.tutorialspoint. com/women_in_leadership/women_in_leadership_introduction.htm.

35. Zupančič, D., 1996. Umetnost vojne. Ljubljana: Založba Amalietti. 